\title{
The Golden Key to Water Ecological Protection
}

\author{
Yuhong Zhai \\ Jiangyan High School of Jiangsu Province \\ Taizhou, China
}

\author{
Deshan Tang* \\ College of Water Conservancy and Hydropower \\ Engineering, Hohai University \\ Nanjing, China \\ tds808@163.com
}

\begin{abstract}
Clean river, unblocked water flow, green bank and gorgeous scenery” has long been yearned for by the People. The document "Comments on Comprehensively Advancing the River Chief System" heralds the innovative upgrading of the river chief system from a local institution to a nationwide water management policy. River Chief System on the one hand is the administration of centralized power of water environment, on the other hand is the strict accountability of the executive power. The ongoing promotion of River Chief System is a panacea for realizing water ecological protection. The principle objectives of this study are to give a clear understanding of River Chief System and to give opinions to perfecting this system. From the perspective of the self-interest of the human development, this study analyzed the fundamental solutions to water ecological protection (i.e., four "Adhere to") and pointed out that developing ecological agriculture and cyclic economy is the root measure for water ecological protection.
\end{abstract}

Keywords-Water ecological protection; golden key; ecological agriculture; cyclic economy; systematic treatment

\section{INTRODUCTION}

Water is the element in forming all the living creatures. For instance, approximately $70 \%$ of an adult body composition is made from water. Looking back on the past, we must deeply introspect how human beings have treated water. Why the rivers and lakes that previously allowed swimming and drinking now turn black and stinky? Why do so many people get cancer after drinking polluted water? Why do flood disasters happen frequently? Basically, neglecting water ecological protection in the imbalanced period of economic development led to these problems.

The CPC Central Committee with General Secretary Xi Jinping as the core has sized up the situation. With the fundamental interests of the people in mind, protecting the water ecology on which human beings depend on for living must be enforced. In December 2016, the Central Office of the CPC Central Committee and the General Office of the State Council have published a document named "Comments on Comprehensively Advancing the River Chief System”. In this document, it has been made clear that "To solving problem we must adhere to being problem-oriented and take actions according to local conditions; implement one policy one river and one policy one lake due to their different locations and plan upstream and downstream, and left bank and right bank as a whole to solve the dominant problems in management and protection of rivers and lakes” [1].
The core of comprehensively advancing the River Chief System is implementing the leading system of party and government, specifically leader responsibility system [2]. The objectives of this implementation are to intensify party and government leaders' role as the first person responsible, thus integrating party committee and government enforceability to the most extent; and to enforce those responsible to take responsibility and fulfill responsibility for river protection, thus solving the difficult problems in river (lake) water ecological protection in China [3]. The simplified organization structure of River Chief System is as shown in Fig.1.

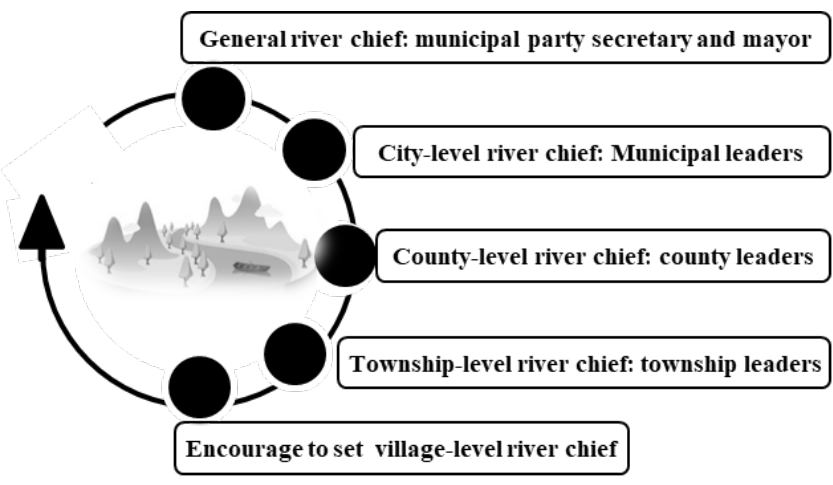

Fig. 1. Simplified organization structure of River Chief System.

The system of river chief originates from local government's institution innovation. The system of river chief has both advantages and disadvantages [4]. The advantages of the system of river chief are clear right power, and duty attribution; rational-institution innovation based on efficient path dependence; pollution governance by iron hand; and innovative diffusion mechanism deserving to be recommended. There are also some disadvantages of the system: unable to eliminate the principal-agent problem, lack of a transparent supervisory mechanism, easy access to conspiracy for benefit, ignoring social forces, weak public participation and supervision and difficult to implement administration accountability.

The system of river chief evaluates comprehensively local power structure and the environmental reality, take full advantage of the chief executive's authority to lead in the function transformation of local governments, and propel the change to of environmental institution with Chinese native characteristic. The system in the past was applied to solve urgent water crisis, now it is in the process of the early 
transition from a crisis management mechanism to long-lasting water ecology protection system.

The people have already put forward higher demands for living quality. Environment, particularly water environment, is the base of all living beings. So we should maximize favorable factors and minimize unfavorable ones of River Chief System in its development, perfecting this system step by step. The system has to be made into an effective and efficient environmental supervisory mechanism with whole social participation, and a sustainable institution of environmental governance should be built [4].

\section{FOUR “ADHERE TO” IS THE FOUNDATION FOR WATER ECOLOGICAL PROTECTION}

The lifeline of human beings lies in water, the lifeline of water lies in mountain (forest), the lifeline of mountains lies in soil and the lifeline of soil lies in water. Mountain, water, soil, forest, river (lake) belong to the same life community, hence water ecological protection is a systematic project which must be urgently investigated and treated. Comprehensively advancing River Chief System is the intrinsic requirement of implementing green development ideology and promoting ecology civilization construction. It is also an effective measure to solve complex water problems and maintain the healthy life of river. Meanwhile, it is an institutional innovation for improving water governance system and water security system $[1,4]$.

In order to strengthen water ecological protection and improve long-term mechanism for river and lake governance and protection, local government is establishing the "One River (Lake) One Policy” implementation program according to local conditions. This program is an important safeguard for building the life community of mountain, water, soil, forest, river (lake). It is also the technical support to establish River Chief System demonstration zone. Meanwhile, it is an important measure to implement the requirements and tasks of comprehensively advancing the River Chief System, and the main basis for promoting water ecological protection. In order to well implement "One River (Lake) One Policy" program, it is necessary to protect the clean water from the source in a combination with extensive field research. According to the requirements of water ecological protection, four fundamental solutions have been stated herein:

\section{A. Adhere to remaining true to the original aspiration and making right prescription for river (lake) protection}

Water is the necessity for industry and the basis for ecology. A good water ecology environment is an inevitable and irreplaceable natural resource and environment element for social and economic development. The symptom of water pollution is embodied in water, while the root cause is reflected on bank. Rural waste pollution(straw, cultivation, domestic waste, etc.), non-point pollution (chemical fertilizer and pesticide), and industrial point pollution turn rivers which were previously suitable for swimming and drinking into stinky drains, which not only harm the drinking water safety of the people, but also harm the current and later generations.
Aiming at the existing problems, a scientific prescription with an in-depth investigation should be made to systematically protect water ecology. By stepwise implementation of the prescription, the river (lake) conservation target which is "clean river, unblocked water flow, green bank and gorgeous scenery" will be realized. A fine geomancy will be created for the health of the people. Water ecological protection is not only a conservation project, a development project, a livelihood project and a conscience project, but also related to the health of each and every person, which should be implemented carefully.

\section{B. Adhere to remaining true to the original aspiration and making right prescription for river (lake) protection}

China has a great number of rivers with different situations. While comprehensively advancing water ecological protection, we must adhere to being problem oriented and make in-depth investigation into the current situation of rivers and lakes. The investigation should cover: 1) basic conditions of main rivers and lakes; 2) water resources and its exploitation; 3) water environment quality; 4) water ecological condition; 5) functioning condition of rivers and lakes 6) management situation of rivers and lakes. After in-depth investigation, aiming at existing problems, we should adhere to the combination of short-term and long-term treatment and the combination of quantitative and qualitative analysis, take the requirement for good life of the people into account and take the improvement of water environment quality as core, then establish a river and lake conservation management mechanism with well-defined duties, orderly coordination, intensive monitoring and powerful protection $[5,6]$.

By 2020, the following objectives are planned to be realized [7]: 1) A modernized river and lake conservation management planning system will be basically established; 2) River and lake management institution, personnel and fund will be fully put into practice; 3) The behavior of human violation on rivers and lakes will be effectively restrained; 4)The nonfunctioning surface water (worse than Grade V),black water and stinky water will be basically eliminated, and water from county-level centralized drinking water source will all achieve or exceed Grade III; 5)The exploitation of rivers and lake resources will be scientific and orderly, the water area will be steady and going up, and the functions of rivers and lakes regarding flood control, water supply and ecology will elevate obviously; 6) The satisfaction and sense of accomplishment from the people will improve obviously [8]; and 7) Green development, healthy development and harmonious development of rivers (lakes) will become the routine. In the foreseeable future, the target of river and lake management which is "clean river, unblocked water flow, green bank and gorgeous scenery” will be realized.

\section{Adhere to the mass line and advancing the full implementation of water ecological protection}

In the recent years, with the rapid development of the economy and society, water pollution, water deterioration and water ecology damage have sprung up. Some rivers are overexploited; some construction projects involving rivers are constructed without the approval; occupation of river way, 
over-standard pollutant discharge, disordered mining and building occur once in a while; in some places, rubbish and sewage are discharged into rivers, which pollute the water body and deteriorate the ecology; some citizens hold insufficient awareness of protecting and saving water; law enforcing departments lack in the law enforcement jurisdiction and tools, leaving some dominant problems repeatedly emerging. All of these problems hinder the continuous improvement and upgrade of water ecology.

Therefore, in order to strengthen water ecological protection, first we need to stick to the principal of "come from the masses, go to the masses". Investigation on river and lake current status should be reinforced. We should widely solicit the opinions and appeals from the masses living along the river (lake) and solicit the opinions and suggestions from all sectors of the community to find out the root causes of river (lake) problems. We need to plan the functions of rivers and lakes as a whole, including flood control, water logging control, water supply, shipping, ecology and landscape functions. We should make the right prescription and implement the treatment dialectically on the basis of System Engineering Theory. Adhering to the principle of seeking advice from the people and serving the people will enable river chiefs at different levels develop a definite objective in view to manage the water ecological protection and adhere to the principle "River is most precious”.

\section{Adhere to systemic treatment and developing ecological agriculture and cyclic economy}

River (Lake) protection is a long-term and complex systematic engineering which includes eight tasks: 1) water resource management, 2) river and lake resource protection, 3) water pollution prevention and treatment, 4) water environment comprehensive treatment, 5) river and lake ecological restoration, 6) long-term river and lake management and protection, 7) supervision of law enforcement on river and lake, and 8) improvement in river and lake comprehensive function[9]. When taking engineering measures, we should also focus on developing ecological agriculture and cyclic economy, which is the fundamental solution to prevent water pollution and improve ecological environment.

Fig. 2 gives a sample of implementation steps of agricultural recycle economy. The development of agricultural recycle economy is the effective approach to realize agricultural sustainable development, which is also an important part in building new socialist countryside. Implementing recycle agriculture is a imperative direction for promoting regional economic sustainable development and modern agriculture construcion.

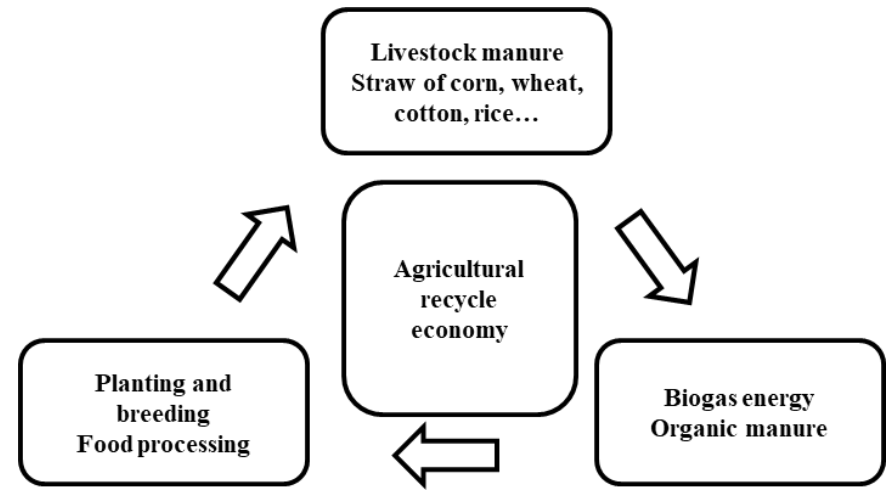

Fig. 2. Conceptual model of implementing agricultural recycle economy.

According to a survey, a pig produces 11 tons of waste water per year (which is one of the main causes of the formation of black and stinky water). However, with rational utilization, this part of waste water could provide organic fertilizer to $0.5 \mathrm{mu}$ ( $1 \mathrm{mu}=0.0667$ hectares) farmland. Besides, careless discard of a lithium battery at the size of a button could pollute 600 tons of water, which is equivalent to the amount of drinking water required for one's whole life. An adult produces $30 \mathrm{~kg}$ of waste water and $2 \mathrm{~kg}$ of trash per day. If all the waste water and trash is not recycled, this will be a big pollution to water environment. The practice of bringing the wasted products back to valuable resources requires efforts from the concerned departments and each citizen. It has been proved that ecological agriculture and cyclic economy is fundamental to the improvement in economy, society and ecological environment. It is not only the inevitable choice for sustainable development, and but also the best option for achieving the goal of "Green mountains remain, clear water runs, rivers stay calm, people live wealthy”.

\section{CONCLUSION}

The great vision that "fish in water, greenery on bank, scenery in greenery, human and water in harmony” is not only the best wishes from the people, but also the target for water ecology protection and the great sign for fully achieving the civilized, prosperous and harmonious society. By comprehensively advancing the River Chief System, accelerating the ecological protection of rivers and lakes, constructing a batch of sample projects of ecological agriculture and cyclic economy, forging a batch of high quality intimate river (lake) scenery, using the engineering and scenic benefits as the source of water ecological protection fund, it is likely to achieve the win-win of water ecological protection and economic development, and finally realize what the Chinese saying always says - "Clear rivers and green mountains are as valuable as mountains of gold and silver”.

\section{ACKNOWLEDGMENT}

This work was partially supported by the Priority Academic Program Development of Jiangsu Higher Education Institutions (PAPD). 


\section{REFERENCES}

[1] J. Zhou and Y. Xiong, "'"The River Chief System": How Is Continuous Innovation Possible?-a Two-Dimension Analysis on the Basis of Both Policy Text and Reform Practice”. Jiangsu Social Sciences. Jiangsu, vol. 4, pp. 938-47, April 2017. (In Chinese)

[2] J. He, D. Wen, and B. Gao, "Research on the Assessment and Control Countermeasures of Iron Contamination in Drinking Water Sources of Xiaoshan Region”, Environmental Monitoring in China. Beijing, vol. 33, pp. 97-105, February 2017. (In Chinese)

[3] X. Ye, "On cross-domain environmental governance--take "river-chief system” as a sample”, Social Sciences of Beijing. Beijing, vol. 5, pp. 108-116, May 2017. (In Chinese)

[4] S. M. Wang, "Critique of the system of river-leader based on the perspective of new institutional economics", China Population Resources \& Environment. Shandong, vol. 21, pp. 8-13, September 2011. (In Chinese)
[5] H. Yu, L. Song, and H. Cheng, "Design and implementation of river protection management system based on river chief mechanism", Journal of Drainage \& Irrigation Machinery Engineering. Jiangsu, vol. 34, pp. 608-614, July 2016. (In Chinese)

[6] M. Ren, "The river-chief mechanism: a case study of china's interdepartmental coordination for watershed treatment”, Journal of Beijing Administrative College. Beijing, vol. 3, pp. 25-31, March 2015. (In Chinese)

[7] Q. Zuo, C. Han, C. Han, Z. Luo, "Study on the theoretical basis and support system of river governor system”, Yellow River. Zhengzhou, vol. 39, pp. 1-6, June 2017. (In Chinese)

[8] J. Guo, "Idea on river-head system implementation in river and lake management of Zhongshan City”, Yangtze River. Hubei, vol. 48, pp. 5-8, July 2017. (In Chinese)

[9] Q. He, ""River administrator" system from perspective of environmental law”, Public Administration \& Law. Jilin, vol. 8, pp. 78-82, August 2011. (In Chinese) 